\title{
Which variables influence the succession process in family farms? A literature review
}

\author{
Víctor Rodriguez-Lizano ${ }^{1, *}$, Mercedes Montero-Vega ${ }^{1}$ and Nicole Sibelet ${ }^{2,3}$ \\ ${ }^{1}$ Department of Agricultural Economics, University of Costa Rica, 11501-2060 San José, Costa Rica \\ 2 CIRAD, UMR INNOVATION, 34398 Montpellier, France \\ ${ }^{3}$ INNOVATION, Univ Montpellier, CIRAD, INRA, Montpellier SupAgro, Montpellier, France
}

\begin{abstract}
The decrease in family farm succession is a problem in many countries worldwide. However, no systematic compilation of relevant studies exists. The method of analysis described in this article enabled us to obtain descriptive statistical results such as: most-studied variables, least-studied variables, patterns in the effects of the variables on succession, new types of variables analyzed, and principal approaches of the qualitative studies. We conducted a literature search in four databases, which resulted in 59 papers relevant to the topic. Twenty-nine of them are quantitative and 30 are qualitative. The literature search in peer-reviewed journals in English resulted primarily in articles from developed countries. Due to this, the selection, analysis and results turned out to be focused on Global North countries. Likewise, the studies considered are focused mainly on the opinion of the principal farmer and disregard that of other family members. From the quantitative studies, we analyzed five groups of variables (farmer, farm, family, context and psychological variables). The farmer variables are the most studied and the context and psychological variables are the least studied. We identified four axes around which the qualitative studies focused: socioeconomic factors, communication between father and heir about the process of succession, integration in decision-making and trust in the heir, and training the successor. Adding new countries (e.g. from Sub-Saharan Africa) and generating new models including psychological, context, and qualitative variables could lead to new ways of understanding such a complex issue.
\end{abstract}

Keywords: review / farm transfer / farm succession / family farms / generational turnover

Résumé - Quelles variables influencent le processus de succession dans les exploitations agricoles familiales? Revue de littérature. Les problèmes de succession dans les exploitations agricoles sont de plus en plus importants dans de nombreux pays du monde. Cependant, aucune compilation systématique des études pertinentes n'existe. L'objectif principal de notre revue de littérature est d'examiner les facteurs quantitatifs et qualitatifs les plus étudiés et d'identifier de nouveaux concepts permettant une compréhension plus large de la question de la succession en agriculture. La méthode d'analyse décrite dans cet article nous a permis d'obtenir des résultats statistiques descriptifs tels que : les variables les plus étudiées, les variables les moins étudiées, les effets des variables sur la succession, les nouveaux types de variables analysées et les principales approches des études qualitatives. Nous avons effectué une recherche dans quatre bases de données d'articles scientifiques pour retenir 59 articles pertinents sur le sujet. Vingtneuf sont de type quantitatif et 30 de type qualitatif. La recherche dans les revues à comité de lecture en anglais a permis de trouver principalement des articles provenant de pays développés. De ce fait, la sélection, l'analyse et les résultats concernent principalement les pays développés. Les recherches portent essentiellement sur l'opinion du chef d'exploitation et ne tiennent pas compte de celle des autres membres de la famille. À partir des études quantitatives, nous avons analysé cinq groupes de variables (agriculteur, exploitation, famille, contexte et composante psychologique). Les variables liées à l'agriculteur sont les plus étudiées, alors que le contexte et les variables psychologiques sont les moins étudiés. Nous avons identifié quatre axes sur lesquels les études qualitatives ont porté : les facteurs socioéconomiques, la communication entre le père et l'héritier sur la succession, l'intégration dans la prise de décision et la

\footnotetext{
*Corresponding author: victorantonio.rodriguez@ucr.ac.cr
} 
confiance en l'héritier, et la formation du successeur. L'ajout de nouveaux pays (par exemple d'Afrique sub-saharienne) et la création de nouveaux modèles qui incluent des variables psychologiques et contextuelles ainsi que des variables qualitatives peuvent conduire à de nouvelles façons d'aborder une question aussi complexe.

\section{Introduction}

More than in any other kind of business, agriculture is strongly linked to family succession since it remains a largely inherited occupation (Lobley and Baker, 2012). The process of transferring management and ownership to the next generation is nowadays perceived as one of the most critical steps for a business to survive, and likewise the most important aspect of social sustainability of family farming (Uchiyama et al., 2008).

Encouragement and improvement of family farming represent key aspects of food security and local and regional development (Graeub et al., 2016). The High-Level Panel of Experts on Food Security and Nutrition (HLPE) defines the family farm concept as agriculture that is "practiced by families using only or mostly family labor and deriving from that work a large but variable share of their income, in kind or in cash" (HLPE, 2013, p. 10). This definition is based on the intensive use of family labor and not on farm size; categorizations of family farms based solely on farm size can be misleading, because the size of a profitable farm can change by "region, production strategy, level of market integration, family structure, access to inputs, technology, and infrastructure, and off-farm labor opportunities" (Graeub et al., 2016, p. 2).

The family farming concept has many acceptations and could become complex and ambiguous. According to Berdegué and Fuentealba (2011) family farmers can be divided into at least three groups:

- those who hire permanent labor and are well-integrated into the market;

- those with significant assets and market integration but facing a lack of key elements (e.g. sufficient credit access) and not able to apply for social safety nets;

- subsistence land-poor farmers with non-market activities who require significant investment in social support.

This research mainly focused on the first two groups, which are the most widespread types in developed countries and some developing countries (Berdegué and Fuentealba, 2011; Eurostat, 2016; Whitt et al., 2019). Nevertheless, these two groups are not necessarily the most common in Asia and Africa, where the vast majority of family farms are located (Lowder et al., 2016).

Despite their importance, family farms, in developed countries and in some developing countries, have an increase in farmers' age on average, are decreasing in number, and have a general reluctance to transfer management from the owning generation to the successor generation (Lobley et al., 2010).

Two main approaches to this situation can be distinguished in the literature. The first one refers to quantitative research in which most publications use socioeconomic variables focused on family, farm and farmer, and conduct a correlation analysis between the variables and the succession status of the farm. The second approach attempts to understand succession from a qualitative point of view, mainly focusing on the description of the succession process and its stages as well as on all the strategies farmers employ so that their relatives can stay on the farm. Other qualitative research highlights topics such as the role of women as new farmers (Kazakopoulos and Gidarakou, 2003), the importance of social (network) capital (Joosse and Grubbström, 2017), the family attachment to the farm because of historical events (Grubbström and Sooväli-Sepping, 2012) and the family's commitment to the agricultural way of life (Brandth, 2019). Bertoni and Cavicchioli (2016) and SuessReyes and Fuetsch (2016) conducted studies related to succession, however, they did not take into account the analysis of succession in developing countries nor the effects of other non-traditional variables such as the psychological ones.

The main objective of this review is to analyze which variables affect, and how, agricultural farm succession in family farms. The research question is: what is the effect of different types of variables on agricultural succession, according to literature?

\section{Methodology}

To conduct the literature search, we utilized an adaptation of the methodology presented by Fink (2010) and applied also by Suess-Reyes and Fuetsch (2016). We used the following steps:

1 selecting bibliographic databases;

2 choosing search terms;

3 applying practical and methodical screening criteria;

4 conducting the review;

5 synthesizing the results.

Regarding step 1 ("selecting bibliographic databases"), we consulted seven databases: DOAJ, Google Scholar, JSTOR, Scopus, Springer, ScienceDirect and Web of Science. In step 2 ("choosing search terms"), we chose for the seven databases the following key words: farm succession/transfer, farm, and family. Each was separated by the Boolean operator "AND" which ensures papers related to family farm succession would appear in the search results. In step 3 ("applying practical and methodical screening criteria"), in order to ensure the use of reliable information, we restricted the literature search to include only scientific papers published in peer-reviewed academic journals in English. The search excluded magazine articles, doctoral theses, book chapters, papers written for conferences, and working papers. The literature search included papers published between January 2000 and June 2019 , the time span in which most of the related literature has been published. Step 3 consisted of the following four phases. 
Table 1. Article selection procedure.

Tableau 1. Sélection des articles.

\begin{tabular}{lrrrrl}
\hline Database & Phase a & Phase b & Phase c & Phase d & $\begin{array}{l}\text { Final } \\
\text { database }\end{array}$ \\
\hline DOAJ & 54 & 9 & 2 & & \\
Google Scholar & 32 & 10 & 3 & & \\
JSTOR & 879 & 16 & 6 & & \\
ScienceDirect & 1117 & 25 & 15 & & \\
Scopus & 114 & 45 & 9 & & \\
Springer & 281 & 10 & 5 & & \\
Web of Science & 111 & 51 & 5 & & 14 \\
Selected papers & 2588 & 166 & 45 & & 59 \\
Total & & & & & \\
\hline
\end{tabular}

Source: prepared by the authors.

\subsection{Phase a}

We conducted an initial search in each of the seven databases with the restrictions mentioned above.

\subsection{Phase b}

Next, we analyzed the title and abstract of each article and excluded those that were not relevant to the topic. This generated 166 papers that were relevant.

\subsection{Phase c}

We analyzed in greater detail the papers that passed the first and second filters and were subject to exclusion for either of the following three reasons:

- the article was about non-agricultural succession;

- agricultural succession was mentioned but was not the central subject of the article;

- or the article referred to descriptive information that contributed little to the topic being studied.

The papers selected showed a main objective or main research question entirely related to: the farm succession process, continuity of the farm, transfer of the farm to the younger generation, drivers that determine whether heirs to stay or leave the farm, or a specific part of the succession process (e.g. planning, communication, gender).

\subsection{Phase d}

Of the papers that passed the previous three phases, we scrutinized the references, which resulted in the addition of 14 new papers.

The number of papers in each phase of step 3 is shown in Table 1.

We began step 4 ("conducting the review") by classifying the papers as either quantitative or qualitative, as Cavicchioli et al. (2015) suggested for this topic. Related to farm succession, quantitative papers are those which exhibit a causal relationship between the dependent variable and different kinds of socioeconomic variables (Bertoni and Cavicchioli, 2016); all of them use econometric models or other nonparametric approaches in order to analyze those relationships. Quantitative papers use different proxies for measuring family farm succession, which is taken as the dependent variable " $y$ ". Some examples of how farm succession is measured via proxy variables are: farm succession is certain or likely (Glauben et al., 2004), farmers think the next generation takes over the farm (Cavicchioli, 2016), farmer has a succession plan (Mishra et al., 2010), if farmer has a family succession plan or not (Mishra et al., 2010), successor declared or at least one child working on the farm, as, "in practice, it has been usually conceived as an indication that this child will eventually be given full ownership of his/her parents' farm" according to Israel's moshavim (cooperative village) culture (Kimhi and Nachlieli, 2001).

For the quantitative papers, we analyzed five groups of variables and their effect on family farm succession. The groups of variables were: farmer, farm, family, context and psychological variables. The first three groups are the same as those proposed by Suess-Reyes and Fuetsch (2016) and Bertoni and Cavicchioli (2016). However, Bertoni and Cavicchioli (2016) add context variables such as the ones related to conditions around the farm (e.g. labor market conditions and degree of rurality or urbanization). The psychological variable corresponds to a new strand of papers related mainly to four factors, which are: farmers' beliefs, farmers' attitude toward succession, perceived behavioral control and normative aspects.

With respect to the qualitative papers, we made a matrix exhibiting the four main points related to the theme of family farm succession. The main points are:

- factors about the farmer, farm, family and context;

- communication between father and son/daughter about the intention of succession;

- training the successor;

- integration in decision-making/confidence in the son/ daughter.

We analyzed the way in which each article treated each of these main points. Next, we placed the most important contributions of each article in the corresponding column and generated a vertical reading system to identify the convergence or divergence of papers around each main point.

Finally, in step 5, we synthesized the results in figures and tables.

\section{Results and discussion}

The results are divided into two subsections, the first one references the quantitative studies ( 29 articles) and the second one analyzes the qualitative studies ( 30 articles). We excluded 60 articles that were written in languages other than English.

\subsection{Quantitative studies}

Most of the studies (62\%) analyze succession via logistic or probabilistic models, which use a binary dependent variable 
Table 2. Descriptive statistics of the farmer variables.

Tableau 2. Statistiques descriptives des variables de l'agriculteur.

\begin{tabular}{|c|c|c|c|c|c|c|c|c|}
\hline \multirow[t]{2}{*}{ Variables } & \multicolumn{8}{|c|}{ Relationship with farm succession } \\
\hline & $\begin{array}{l}\text { Positive } \\
\text { relationship }\end{array}$ & $\begin{array}{l}\% \text { from } \\
\text { included }\end{array}$ & $\begin{array}{l}\text { Negative } \\
\text { relationship }\end{array}$ & $\begin{array}{l}\% \text { from } \\
\text { included }\end{array}$ & $\begin{array}{l}\text { Not } \\
\text { effect }\end{array}$ & $\begin{array}{l}\% \text { from } \\
\text { included }\end{array}$ & $\begin{array}{l}\text { Not } \\
\text { included }\end{array}$ & $\begin{array}{l}\% \text { from all } \\
\text { quantitative } \\
\text { papers }\end{array}$ \\
\hline Farmer age & 13 & 68 & 2 & 10 & 4 & 22 & 10 & 34 \\
\hline Farmer gender ${ }^{1}$ & 4 & 57 & 3 & 43 & 0 & 0 & 22 & 76 \\
\hline Farmer degree & 7 & 41 & 8 & 47 & 2 & 12 & 12 & 41 \\
\hline Off-farm job & 2 & 13 & 6 & 40 & 7 & 47 & 14 & 48 \\
\hline \multicolumn{7}{|c|}{ Average not included } & 16 & 55 \\
\hline
\end{tabular}

Source: prepared by the authors.

${ }^{1}$ Positive relationship refers to a better probability of succession if the principal farmer is a man.

$(Y)$. Conversely, in multinomial methodology, the dependent variable $(Y)$ represents more than two scenarios. These models are intended to better capture the complexity of family farm succession. However, out of 29 quantitative papers, only three conducted multinomial models. The sample sizes used are large, typically over 200 observations. In this case, we account for significant effects of specific variables in family farm succession, which is obtained in most of the cases by hypothesis/significance tests at a certain probability threshold (e.g. $t$-test at 95\%). This allows us to directly compare the results of different sample sizes.

From the quantitative papers gathered, $18(62 \%)$ analyze case studies from Europe, four (14\%) from North America, three (10\%) from Asia, two (7\%) from Latin America, one (3\%) from Africa and one (3\%) from Oceania. The majority $(62 \%)$ conducted the analysis using binary regression models (probit or logit). Likewise, $16(56 \%)$ were focused solely on the principal farmer's opinion, seven (24\%) focused on successor willingness to take over the farm, five (17\%) focused on opinions of both successor and principal farmer, and only one $(3 \%)$ on various family members.

The results for the "farmer" variables are shown in Table 2.

In general, we found a positive relationship with respect to succession in that the older the farmer the more likely the farm is passed to the next generation. This result is intuitive since it is not common to see farmers retire at a young age, however, studies by Glauben et al. (2004b), Kerbler (2012), Kimhi and Nachlieli (2001) and Stiglbauer and Weiss (2000), indicated an $n$-shaped (concave down) relationship in this variable, such that with increasing age of the farmer the likelihood that family farm succession will occur also increases, however, as of a certain age the probability of succession decreases. The age at inflection point is in some cases greater than 80 years, as happened in the case of Italy (Corsi, 2009) and moshavim (cooperative villages) in Israel, where all farmers have an equal amount of land and farm property could not be used as collateral for commercial loans (Kimhi and Nachlieli, 2001).

The variable "principal farmer's gender" showed an effect on succession in all cases. In the study conducted by Glauben et al. (2004) in upper Austria, the likelihood of succession is higher for female farm operators, and in addition to this, farm succession take place earlier. The same correlation was made by Cavicchioli et al. (2015) in the Lombardy mountains, on apple-producing farms with "protected geographical indication" (AOP) status. Four studies show that farms run by males have better probability of farm succession (Bertoni and Cavicchioli, 2016; Kerbler, 2008; Stiglbauer and Weiss, 2000; Zou et al., 2018)

Regarding "farmer degree", this variable should be treated carefully, because depending on the situation of the farm, context and type of farmer education, this variable could trigger a positive or negative impact on succession. For example: "Perhaps better-educated parents can more easily and efficiently work out a solution to the bargaining game with the potential successors, thereby allowing themselves to reach an earlier succession decision without increasing the risk of making a bad decision" (Kimhi and Nachlieli, 2001). On the other hand, Glauben et al. (2004) showed that family farm succession could be negatively affected by the educational level of the father. Others, such as Mishra and El-Osta (2008), link a higher education level of the incumbent with higher rate of family farm succession, this is because a higher level of education implies greater skills, which, if employed for farming entail a greater farm profitability, something that is more attractive for prospective successors. The latter authors used farm-level data to investigate the impact of government farm policy and farm growth on both succession decisions and the likelihood of intra-family transfers of the farm business. This research, used a particularly large sample of more the one million US farm operators 45 years of age or older.

With respect to the variable "off-farm job", seven (54\%) studies showed that there is no effect on family farm succession (Aldanondo Ochoa et al., 2007; Cavicchioli et al., 2015; Glauben et al., 2009, 2004; Kimhi and Nachlieli, 2001; Mishra and El-Osta, 2007, 2008). On the other hand, six $(40 \%)$ reported a negative relationship (Arowolo et al., 2017; Cavicchioli et al., 2019; Corsi, 2009; Hennessy and Rehman, 2007; Kerbler, 2012; Zou et al., 2018) and a minority showed that it can have a positive effect (Kerbler, 2012; Mishra and ElOsta, 2010). The majority of studies quantified this as a dichotomous variable and only five studies measured it as a continuous variable as a percent of total income, which can lead to differences in the results. In general, the results tend to show that having an off-farm job either has no effect or has a negative effect on succession. Regarding the negative effect, if the principal farmer has an off-farm job, it could positively 
Table 3. Descriptive statistics for the farm variables.

Tableau 3. Statistiques descriptives des variables de l'exploitation agricole.

\begin{tabular}{|c|c|c|c|c|c|c|c|c|}
\hline \multirow[t]{2}{*}{ Variables } & \multicolumn{8}{|c|}{ Relationship with farm succession } \\
\hline & $\begin{array}{l}\text { Positive } \\
\text { relationship }\end{array}$ & $\begin{array}{l}\% \text { from } \\
\text { included }\end{array}$ & $\begin{array}{l}\text { Negative } \\
\text { relationship }\end{array}$ & $\begin{array}{l}\% \text { from } \\
\text { included }\end{array}$ & $\begin{array}{l}\text { Not } \\
\text { effect }\end{array}$ & $\begin{array}{l}\% \text { from } \\
\text { included }\end{array}$ & $\begin{array}{l}\text { Not } \\
\text { included }\end{array}$ & $\begin{array}{l}\% \text { from all } \\
\text { quantitative } \\
\text { papers }\end{array}$ \\
\hline Capital & 7 & 70 & 0 & 0 & 3 & 30 & 19 & 66 \\
\hline Specialization & 6 & 86 & 1 & 14 & 0 & 0 & 22 & 76 \\
\hline Growth & 7 & 78 & 1 & 11 & 1 & 11 & 20 & 69 \\
\hline Average not included & & & & & & & 19 & 65 \\
\hline
\end{tabular}

Source: prepared by the authors.

Table 4. Descriptive statistics for the "family" variables.

Tableau 4. Statistiques descriptives des variables de la «famille».

\begin{tabular}{|c|c|c|c|c|c|c|c|c|}
\hline \multirow[t]{2}{*}{ Variables } & \multicolumn{8}{|c|}{ Relationship with farm succession } \\
\hline & $\begin{array}{l}\text { Positive } \\
\text { relationship }\end{array}$ & $\begin{array}{l}\% \text { from } \\
\text { included }\end{array}$ & $\begin{array}{l}\text { Negative } \\
\text { relationship }\end{array}$ & $\begin{array}{l}\% \text { from } \\
\text { included }\end{array}$ & $\begin{array}{l}\text { Not } \\
\text { effect }\end{array}$ & $\begin{array}{l}\% \text { from } \\
\text { included }\end{array}$ & $\begin{array}{l}\text { Not } \\
\text { included }\end{array}$ & $\begin{array}{l}\% \text { from all } \\
\text { quantitative } \\
\text { papers }\end{array}$ \\
\hline Offspring number ${ }^{1}$ & 8 & 58 & 3 & 21 & 3 & 21 & 15 & 52 \\
\hline Child gender & 5 & 83 & 0 & 0 & 1 & 17 & 23 & 79 \\
\hline Child lives on farm & 4 & 100 & 0 & 0 & 0 & 0 & 25 & 86 \\
\hline Average not included & & & & & & & 21 & 72 \\
\hline
\end{tabular}

Source: prepared by the authors.

${ }^{1}$ Number of sons or daughters of the farmer.

influence the heir's choice toward works outside the farm (Hennessy and Rehman, 2007). However, there is an open discussion about the effect of the off-farm job depending on if it is perceived as the main or secondary occupation of the farmer (Corsi, 2009). Also, in order to be able to work off the farm, the production of the farm may have to be reduced which increases the probability of departure from farming (SuessReyes and Fuetsch, 2016), this phenomena is also exposed by Hennessy and Rehman (2007) in which dairy farms are considered as a time-consuming and time-specific activity that make the operation of a part-time dairy business quite difficult, in this case the off-farm job shows a clearly negative effect on farm succession.

The results for the "farm" variable are shown in Table 3.

The farm variables are not often included in the papers, however from the papers that considered them, we could extract four variables that tend to positively influence family farm succession. These are: capital, specialization, nonconventional production, growth and wealth. All of these variables show "no effect" in less than $30 \%$ and little to no percentage of "negative effect". Regarding the variable "growth", a general remark is that once an operator has decided to increase the size or intensity of operation, it is more likely that he/she has a succession plan (Mishra and El-Osta, 2008).

Table 4 shows the results of the "family" variables.
The results related to number of heirs show that the more children there are, the more likely the farm will be succeeded. However, this variable should be treated with care since it can also have a negative effect on succession, in cases where several children would like to work on the farm but it is not big enough to provide sufficient income for everyone. This scenario is explained by Cavicchioli et al. (2015) in small specialized fruit farms in northern Italy. These results suggest that for each farm there are a number of heirs that maximizes the probability of succession, and if this is exceeded, the probability begins to decrease.

With respect to gender, the fact that there are male descendants increases the probability of farm succession. This result has been observed by Cavicchioli et al. (2015, 2018), Glauben et al. (2009), Kerbler (2008, 2012), Suess-Reyes and Fuetsch (2016).

Regarding the variable "child lives on farm", the fact that the residence is located on the farm has a positive effect on family farm succession. The variable "successor education level" should be treated with care since Cavicchioli et al. (2015), Hennessy and Rehman (2007) and Kerbler (2008) showed that if the children pursue studies in agriculture, the probability of farm succession increases. Thus "successor educational level" should be studied in two ways, one as the "number of years of study", the other in terms of relation or not with the agricultural sector. This distinction should be made in 
Table 5. Descriptive statistics for the context variables.

Tableau 5. Statistiques descriptives des variables de contexte.

\begin{tabular}{|c|c|c|c|c|c|c|c|c|}
\hline \multirow[t]{2}{*}{ Variables } & \multicolumn{8}{|c|}{ Relationship with farm succession } \\
\hline & $\begin{array}{l}\text { Positive } \\
\text { relationship }\end{array}$ & $\begin{array}{l}\% \text { from } \\
\text { included }\end{array}$ & $\begin{array}{l}\text { Negative } \\
\text { relationship }\end{array}$ & $\begin{array}{l}\% \text { from } \\
\text { included }\end{array}$ & $\begin{array}{l}\text { Not } \\
\text { effect }\end{array}$ & $\begin{array}{l}\% \text { from } \\
\text { included }\end{array}$ & $\begin{array}{l}\text { Not } \\
\text { included }\end{array}$ & $\begin{array}{l}\% \text { from all } \\
\text { quantitative } \\
\text { papers }\end{array}$ \\
\hline Associated $^{1}$ & 4 & 100 & 0 & 0 & 0 & 0 & 25 & 86 \\
\hline Remoteness & 0 & 0 & 9 & 90 & 1 & 10 & 19 & 65 \\
\hline Government payments ${ }^{2}$ & 4 & 57 & 0 & 0 & 3 & 43 & 22 & 76 \\
\hline
\end{tabular}

Source: prepared by the authors.

${ }^{1}$ If the farm is associated to an organization (e.g. cooperative or a branch).

${ }^{2}$ Government direct payments.

order to capture the impact of this variable, as agriculturerelated education increases the probability of farm succession.

The relevant results for "context" variables are shown in Table 5 .

In general, farmers who are associated to an organization, such as a cooperative, are more likely to succeed the farm, a result supported by Bertoni and Cavicchioli (2016), Cavicchioli et al. (2018), Corsi (2009) and Kerbler (2012). For example, as Corsi (2009) mentioned, family farms associated to cooperatives are more likely to have a successor; this study was conducted in the Piedmont region of Italy and took into account 10,000 family farms of fruits, quality viticulture, cattle or dairy.

The variable "remoteness" always has a negative effect on family farm succession (Aldanondo Ochoa et al., 2007; Cavicchioli et al., 2018; Glauben et al., 2004; Kerbler, 2012; Mann, 2007a; Mishra and El-Osta, 2010; Rayasawath, 2018). As such, farms located farther from developed or commercial areas have less propensity to be succeeded. This variable was of particular interest for Kerbler (2012): in his study of Slovenian farms, remoteness is determinant: "On $60.3 \%$ of farms whose owners believe they are remote, isolated, and distant from the nearest administrative centers and main road in the valley, there will be no takeover... Conversely, $79.6 \%$ of farms whose owners do not consider them remote or isolate will be taken over and continue to be worked" (Kerbler, 2012, p. 293).

From the literature consulted, other variables are included in two or fewer articles; therefore, we did not conduct the formal quantification. Such variables are: population density of the area where the farm is located, level of unemployment in the area where the farm is located, percentage of people employed in agriculture of the total inhabitants, and difference in agriculture versus non-agriculture income in the area where the farm is located.

According to Fischer and Burton (2014), the Tables 2, 3, 4 and 5 correspond to the "factor based" approach, where succession is the result of a mixture of favorable factors. According to these authors, this approach was not robust enough to explain family farm succession; this is because it conflates the connection between training of the successor and farm identity with other non-traditional factors.
The following four articles explain family farm succession through the use of non-traditional variables, especially through the use of psychological ones. Three out of four approached the subject based on the Theory of Planned Behavior (TPB) set forth by Ajzen (1991); these studies are Morais et al. (2017, Morais et al. (2018)2018) and Nuthall and Old (2017). This kind of research focuses on how the study subject's attitude (ATT), normative perceptions (NP) and perceived control behavior (PCB) influence farm succession. The fourth article focused on the endogenous and exogenous factors that prevent young farmers from leaving the farm in several UK counties (May et al., 2019).

Related to the papers based on the TPB, a positive evaluation of taking over the family farm assets is a factor that significantly affects the successor's intention to stay on the farm (Morais et al., 2017). Likewise, the PCB is determinant in explaining the successor's intentions to take over the farm; for example, the successor's perception of his/her own capabilities in managing the farm (Morais et al., 2018) or the ease to buy more land (Morais et al., 2017) are key elements in young Brazilian farmers of soybean, corn, maize and beef. May et al. (2019) also found a positive relation between the "sense of control over the farm" and the decision to remain working in the farm.

Regarding the normative factors, they are usually analyzed both at the family level and at the neighbor level. Social pressure is an explanatory factor in the intention to take over the farm; however, what other young people do does not determine the successor's intention (Morais et al., 2018). On the other hand, it seems that father's and mother's opinions are the most influential factors (Morais et al., 2017) on young farmers.

Nuthall and Old (2017) centered their study on the incumbent farmer's opinion rather than on the successor's belief as Morais et al. (2017, Morais et al. (2018)2018) did. Regarding NP, Nuthall and Old (2017), found that giving importance to maintaining the respect of other farmers as well as to maintain a presence in the community, corresponds to the farmer's positive intention toward having a successor which is positively related to the percentage of assets transferred to the successors by the time of the research. In line with this, May et al. (2019) also found that for young farmers (22 years old on 
average), the opinion of neighbors does weigh in on the successor's decision to take over the farm. This result was obtained through the statement "neighboring farmers could resent the idea of additional subsidy to young farmers". "It appears that farmers who agree to this statement are influenced by the opinion of neighbors implying that negative opinions may reinforce young farmers' incentives to leave the farm" (May et al. 2019, p. 324)

Finally, the highest impact in the research conducted by May et al. (2019) is the one related to the beliefs about the farming sector. These authors found that the opinion of the successor regarding the future of farming (in general) and about the expected profits, are the main factors that trigger the decision of staying or leaving the farm.

\subsection{Qualitative studies}

Articles considered in this research analyzed family farm succession, mainly through direct interviews with farmers in different regions. Generally, qualitative research focuses mostly on perception and lifestyle variables of the principal farmer and on a lesser degree on socioeconomic variables.

The incumbent's perception of farming is a determining variable in family farm succession. The fact that the principal farmer feels unsatisfied with an agricultural way of life determines farm succession according to Hautaniemi and Gutmann (2006); in this regard, US farmers consider the need to match their desires to reality, which means retirement is a lengthy process that could become complicated for elderly farmers, their sons and the economic well-being of both of their families with the same land. Therefore, the "agricultural way of life" does not only consider economic aspects, but also preferences and psychological aspects regarding family dynamics. These variables' importance in succession can vary from region to region; for example, Carolan (2018) exposed that factors such as "importance of living in a rural area", "importance of keeping this farm in the family" and "importance of preserving the family farm" carry more weight than socioeconomic aspects in the rural-urban interface adjacent to Omaha (Nebraska), or Des Moines (Iowa).

As mentioned above, socioeconomic variables also play an important role in farm succession. Several studies referred to larger farms as having greater prospects for succession (Downey et al., 2016; Fischer and Burton, 2014; Grubbström and Sooväli-Sepping, 2012; Hautaniemi and Gutmann, 2006; Uchiyama et al., 2008). Likewise, Fischer and Burton (2014) mentioned that on large farms there is less friction between people and therefore better succession. Moreover, small farms can often only provide for one family, which is represented by expressions such as "there's really only enough for ourselves" (farmer and his wife interviewed by Downey et al., 2016).

Farm size is a proxy not only for economic well-being, but also for more capital available for investment, since farmers have physical space and capital for investment. Therefore, it is expected that farms with more capital have more possibilities for succession (since investments have already been made). Inwood and Sharp (2012) observed that nearly all farmers with an heir ready to take over the farm have long-term investments. On the other hand, smaller farmers such as those located in developing countries, may face even greater difficulties in farm succession. For example: first-generation farmers owned a farm, which was divided into four for each of the heirs. Later on, these second-generation farmers divided their land once again, and so forth. This reality leaves current farmers with smaller-sized farms than their ancestor (at least for inherited land), without technological improvements, and with less capital.

Alongside with farm-size, land price is considered as a decisive factor in family farm succession and the entrance of new farmers in the industry (Creighton et al., 2016; Fischer and Burton, 2014; Joosse and Grubbström, 2017). If the price of land is high, it becomes difficult not to sell the land to developers; likewise, high land prices mean high initial investments that are prohibitive for new farmers (Creighton et al., 2016; Otomo and Oedl-Wieser, 2009). Urban expansion, in many cases, provokes not only higher land prices, but also land scarcity (Carolan, 2018).

Since moving-out of farming and selling the farm is a possibility for all farmers, the employment rate gap is a structural factor that has been identified as having an inverse relationship to family farm succession. The more the urban employment rate exceeds the rural employment rate, the greater will be the exit of rural youth, as studied in Greece by Kazakopoulos and Gidarakou (2003). Furthermore, when the principal farmer and/or spouse have an off-farm job, Hautaniemi and Gutmann (2006) found that the family can stay on the farm indefinitely, since, in this case, farm production is a complement to the income, which is a detriment to succession. Having a retirement pension that is not sufficient to meet the farmer's needs has a similar effect (Grubbström and Sooväli-Sepping, 2012). These aspects would especially influence succession when farming is not the main activity of the family, since it is not as important as in families where all income comes from agriculture.

In this regard, and considering the urban pressure for farmers to change their source of income when farm prices are high, having two generations, or even multiple samegeneration farmers working on the farm at the same time, can cause friction and misunderstanding, which may also limit the possibilities of a healthy succession in the long run (Pitts et al., 2009). There may be disagreements not only about how to manage the farm but also even about whether or not to keep the farm, since it may be attractive for some heirs or their parents to sell it. Thus, when land prices are high, staying on the farm can only be possible if there is a strong attachment to the farm within the family (Cassidy and McGrath, 2014).

Unknown or mismatched aspirations and expectations are key factors against farm succession; this factor was accounted for by Santhanam-Martin et al. (2019) in Australian dairy farms. In this regard, Fischer and Burton (2014) described "bad chemistry" as a factor that negatively affects succession. In fact, studies such as those by Ingram and Kirwan (2011) or Joosse and Grubbström (2017) showed that friction between father and heir is a determining factor in the younger person's decision to exit agriculture. In addition, the existence of several descendants and the distinct interests that each may have in the farm, can have a negative effect on succession.

As pointed out by Suess-Reyes and Fuetsch (2016), family conflicts are usually based on paradox patterns resulting from contradictory expectations between successor and incumbent; these kinds of friction are usually correlated with negative succession scenarios. Finally, the family's tradition in 
agriculture has a direct influence. In traditional agricultural families, the farm is seen as a family project (Grubbström and Sooväli-Sepping, 2012), agriculture is considered a way of life (Brandth, 2019) and people share an ideology that the priority is to succeed the farm (Conway et al., 2017). Once again, the entire succession process has intense emotional implications for the principal farmer (Conway et al., 2017). More than socioeconomic variables are entangled in these decisions, which are based partly on strategic decisions and partly on family-farm related emotions, such that the lack of succession can trigger family turmoil (Mann, 2007b). Farm succession represents more than just handing over the farm, it represents successful aging, which encompasses aging with dignity, financial security, independence, self-fulfillment, and personal safety and security (O'Callaghan and Warburton, 2017).

Since family dynamics seem to play such an important role, some studies have analyzed these dynamics and patterns. In successful cases, the heir must start making decisions about the farm, a concept referred to as "farm ladder" (Errington, 1998), and whose first phase is that of assisting the principal farmer without really being involved in decision-making (Joosse and Grubbström, 2017). Including the successors in farm decision-making is affected by the principal farmer's confidence in them (Brandth, 2019; Fischer and Burton, 2014). Similarly, the discrepancies between parental desires and their child's aspirations in regard to farming as a career choice can cause friction, which in the end can trigger the exit of the younger person from the farm. In line with this is evidence from Norway that a new generation of fathers practice childcare as a kind of "intensive parenting", because fathers increasingly understand the importance of equipping children with the skills and competence required in the late modern society. This kind of parenting can have a significance impact on farm succession (Brandth and Overrein, 2013).

The following are examples of how the father's lack of confidence negatively affected his willingness to include the heir in decision-making and, therefore, family farm succession. A successor's feeling in the Fischer and Burton (2014) study: "He felt his father was constantly 'breathing down his neck' while he was working and how his father did not trust his farming skills and knowledge". A principal farmer's feeling in the Conway et al. (2017) study: "My son is a fairly good worker, but honestly, when it comes to making the difficult decision and situations, I just don't think he is capable of being able to handle them the way I can".

Also in this regard, socialization from a young age about the father's intention to succeed the farm is fundamental (Carolan, 2018; Firman et al., 2018). Not only does it create an expectation from both the incumbent and his heir, but also because it is part of good family dynamics. This has the potential to bring about better understanding between families and also better decision-making. As was previously mentioned, farm investments are related to a better succession outcome. If the decision-making about investments is coordinated between incumbents and heirs, a plan has to be discussed which drives the family conversation toward a healthy succession pattern. The fact that communication is almost never explicit can cause problems since many farmers do not plan to retire (Hautaniemi and Gutmann, 2006), or to the contrary, do not plan on the farm being the principal source of income for the children (Grubbström and Sooväli-Sepping, 2012).

Sadly, since communication is often not explicit, the successor has to assume the message that the father wants to convey; (Pitts et al., 2009). For example, “The son's response to being asked if he thinks his parents expected him to take over the farm suggests that he 'simply knew' without them having to be explicit" (Fischer and Burton, 2014). According to this topic, Chiswell and Lobley (2018) mentioned that in the past, potential successors were usually male and the eldest son. Nowadays, younger potential successors carefully analyze career decisions, during which farming is subject to the same scrutiny as other nonagricultural opportunities; in this context, communication plays an important role. In some specific cases, for example in the German-heritage farming community in Southern Wisconsin, they tried to keep the "yeoman" goal of keeping the farm with the same family name, and so the incumbent is constantly innovating in order to match the cultural traditions with a greatly altered context of agricultural production; in this case, communication also plays a crucial role in order to establish new arrangements between the younger and older generations (Lequieu, 2015).

Therefore, it is usually through actions that the principal farmer shows an interest in the successor remaining on the farm. For example, large capital investments such as the purchase of a tractor when the heir begins his or her studies (Fischer and Burton, 2014) or structural changes in the farm such as not renewing an employee's contract so that the heir can take the place (Fischer and Burton, 2014). Nonetheless, in less-developed agriculture or for poorer farmers, these investments are more difficult to obtain: although the principal farmer may want succession to occur, he cannot demonstrate it by acquiring better technology. In those cases, direct communication becomes even more important, since intention cannot be demonstrated by economic actions.

Regarding the socio-economic variables considered for analysis of family-farm succession, education has also been addressed. Kazakopoulos and Gidarakou (2003) stated that $88 \%$ of the new farmers in their study had attended training courses related to agriculture. In successful cases, this training was, in general, done in parallel to working on the farm. For example, Brandth (2019), observed that "the younger farmer worked for the older farmer while he was still in college and gradually took on the job"; or, as Fischer and Burton (2014) pointed out, where the heir supposed that he or she was going to take over the farm, he or she studied agriculture at the university and returned during breaks to help on the farm.

Some actions relative to family dynamics we identified with successfully succeeded farms are:

- entrusting land to see how the successor manages it and entrusting more land over time depending on the results (Hautaniemi and Gutmann, 2006);

- letting each potential successor be in charge of a certain crop (Inwood and Sharp, 2012);

- co-decision-making about seeds, livestock feed and purchase of equipment (Fischer and Burton, 2014).

Succession is seen as a process that has intense emotional implications for the principal farmer (Conway et al., 2017), since "retirement" is not usually seen as a desirable stage of life 
and due to the sentimental ties with the land and the farming lifestyle (Wheeler et al., 2012).

Finally, cultural aspects play an important role in succession. How farmers perceive the meaning of retirement and aging, as well as gender roles, are mayor cultural aspects considered by several authors (Cassidy, 2019; Glover, 2014). For example, in Ireland, a study by Conway et al. (2017) clearly showed that the concept of retirement is not well accepted, as suggested by expressions such as "You lose hope, you go downhill fast, and that is sad". Conway et al. (2017) identified that this perception against retirement is the most influential factor, since the farmers themselves generate a negative atmosphere around succession, expounding on the consequences of leaving the farm to a younger person. In addition, they often exaggerate the negative consequences of older farmers retiring. In this regard, studies are limited and there are also site specific perceptions of aging.

Another cultural aspect has to do with leaving the farm to a man instead of a woman, a pattern that was repeated several times (Downey et al., 2016; Fischer and Burton, 2014; Hautaniemi and Gutmann, 2006; Tsutsumi, 2001). In this regard, gender and the perception of gender roles play a crucial decision-making role for incumbent males to pass on their farms to women (Chiswell and Lobley, 2018; Tetteh and Boehlje, 2019). Gender discrimination is still a major issue worldwide and it plays a major role in farm and land succession in agriculture (Pitts et al., 2009). Sometimes, daughters are not even considered for farm succession only because of their gender (Tetteh and Boehlje, 2019). Once again, however, most studies were conducted in developed regions; further studies including cultural aspects in developing regions are necessary to have more concluding remarks and site-specific results.

\section{Conclusion}

There is a need for more complex modeling to account for nonlinear relations and multinomial measurements of farm succession. Exploring more psychological variables and considering other family members' opinions rather than just that of the principal farmer could lead to a better understanding of family farm succession. In this regard, the use of modeling techniques such as Structural Equation Modeling (SEM), which allows the analysis of non-observable psychological variables (latent) along with classic socioeconomic variables, could have better results from a quantitative point of view.

Given that the results of our literature review turned out to be focused on Global North countries, expanding future studies to include countries in the Global South and articles in other languages would increase the geographic coverage. This expansion would add more variables and complexity to the modeling techniques, which is part of the challenges of future investigations.

We are aware that family farm succession is a multifactorial process explained by a combination of factors in each specific agricultural situation and context; however, the straight comparison of the same socioeconomic variables amongst countries with widely different social, cultural and production profiles leads to identified variables that show a consistent effect on farm succession, no matter the social, cultural or economic conditions. Examples of highly consistent farm and farmer variables are: farmer age, capital, specialization, growth, wealth, non-conventional production, farm remoteness and association of the farmer to a cooperative or a similar organization. Given the research criteria, capital could be the most important variable in this regard, because the level of capital is usually positively associated with wealth, specialization and even with farmer age. Given this, from the traditional approach, capital could be a good diagnostic variable in order to predict family farm succession. Regarding family characteristics, there is a clear tendency to prefer a male successor to a female successor, thus this is the variable that can be considered as the most important amongst the family variables. Since this research was mainly focused on developed countries, these results cannot be generalized to other latitudes or less formal types of farms.

According to the results and the countries accounted for, positive family farm succession is associated to delegating functions of increasing importance on the farm. Conversely, farms where administrative control is not ceded are associated to negative succession scenarios.

For other types of variables, it is difficult to establish conclusive relationships given the small number of existing studies and the diversity of results. For example, all of the context variables, marital status, land tenure, off-farm job, and if child lives on farm, are above $70 \%$ in the "not included" section of the studies analyzed. This leaves room for future studies to include these little-studied explanatory variables.

Conflicts of interest. The authors declare that they have no conflicts of interest in relation to this article.

\section{Funding information}

We want to thank the University of Costa Rica for funding this project that was conducted during the doctoral studies of the main author.

\section{References}

Ajzen I. 1991. The theory of planned behavior. Organizational Behavior and Human Decision Processes 50(2): 179-211. DOI: 10.1016/0749-5978(91)90020-T.

Aldanondo Ochoa AM, Casanovas Oliva V, Almansa Sáez C. 2007. Explaining farm succession: the impact of farm location and offfarm employment opportunities. Spanish Journal of Agricultural Research 5(2): 214-225. DOI: 10.5424/sjar/2007052-241.

Arowolo OO, Ogunrombi AA, Apantaku SO, Adeogun SO. 2017. Perception of farm succession planning by poultry farmers in Southwest, Nigeria. Journal of Agricultural Extension 21: 80-94. DOI: 10.4314 jae.v21i1.7.

Berdegué J, Fuentealba R. 2011. Latin America: The state of smallholders in agriculture. In: IFAD Conference on New Directions for Smallholder Agriculture. Presented at the IFAD Conference on New Directions for Smallholder Agriculture, IFAD, Rome.

Bertoni D, Cavicchioli D. 2016. Process description, qualitative analysis and causal relationships in farm succession. CAB Reviews - Perspectives in Agriculture Veterinary Science Nutrition and Natural Resources: 1-11. DOI: 10.1079/PAVSNNR201611043. 
Brandth B. 2019. Farmers framing fatherhood: everyday life and rural change. Agriculture and Human Values 36: 49-59. DOI: 10.1007/ s10460-018-9887-z.

Brandth B, Overrein G. 2013. Resourcing children in a changing rural context: fathering and farm succession in two generations of farmers. Sociologia Ruralis 53: 95-111. DOI: 10.1111/soru.12003.

Carolan M. 2018. Lands changing hands: experiences of succession and farm (knowledge) acquisition among first-generation, multigenerational, and aspiring farmers. Land Use Policy 79: 179-189. DOI: 10.1016/j.landusepol.2018.08.011.

Cassidy A. 2019. Female successors in Irish family farming: four pathways to farm transfer. Canadian Journal of Development Studies 40: 238-253. DOI: 10.1080/02255189.2018.1517643.

Cassidy A, McGrath B. 2014. The relationship between 'nonsuccessor' farm offspring and the continuity of the Irish family farm. Sociologia Ruralis 54: 399-416. DOI: 10.1111/soru.12054.

Cavicchioli D, Bertoni D, Frisio DG, Pretolani R. 2019. Does the future of a farm depend on its neighbourhood? Evidence on intrafamily succession among fruit and vegetable farms in Italy. Agricultural and Food Economics 7: 10. DOI: 10.1186/ s40100-019-0129-5.

Cavicchioli D, Bertoni D, Pretolani R. 2018. Farm succession at a crossroads: the interaction among farm characteristics, labour market conditions, and gender and birth order effects. Journal of Rural Studies 61: 73-83. DOI: 10.1016/j.jrurstud.2018.06.002.

Cavicchioli D, Bertoni D, Tesser F, Frisio DG. 2015. What factors encourage intrafamily farm succession in mountain areas? Mountain Research and Development 35: 152-160. DOI: 10.1659/MRD-JOURNAL-D-14-00107.1.

Chiswell HM, Lobley M. 2018. "It's definitely a good time to be a farmer": understanding the changing dynamics of successor creation in late modern society. Rural Sociology 83: 630-653. DOI: 10.1111/ruso.12205.

Conway SF, McDonagh J, Farrell M, Kinsella A. 2017. Uncovering obstacles: the exercise of symbolic power in the complex arena of intergenerational family farm transfer. Journal of Rural Studies 54: 60-75. DOI: 10.1016/j.jrurstud.2017.06.007.

Corsi A. 2009. Family farm succession and specific knowledge in Italy. Rivista di Economia Agraria 64: 13-30.

Creighton J, Blatner KA, Carroll MS. 2016. For the love of the land: generational land transfer and the future of family forests in Western Washington State, USA. Small-Scale Forestry 15: 1-15. DOI: $10.1007 / \mathrm{s} 11842-015-9301-2$.

Downey H, Threlkeld G, Warburton J. 2016. How do older Australian farming couples construct generativity across the life course?: a narrative exploration. Journal of Aging Studies 38: 57-69. DOI: 10.1016/j.jaging.2016.04.007.

Errington A. 1998. The intergenerational transfer of managerial control in the farm-family business: a comparative study of England, France and Canada. The Journal of Agricultural Education and Extension 5: 123-136. DOI: 10.1080/ 13892249885300241.

Eurostat. 2016. Farm structure survey. [2019/11/09]. europa.eu/rapid/ press-release_STAT-18-4298_en.htm.

Fink A. 2010. Conducting research literature reviews: from the internet to paper, 3era ed. Los Angeles, USA: SAGE.

Firman A, Budimulyati L, Paturochman M, Mumun S. 2018. Succession models on smallholder dairy farms in Indonesia. Livestock Research for Rural Development 10(30): 176.

Fischer H, Burton RJF. 2014. Understanding farm succession as socially constructed endogenous cycles. Sociologia Ruralis 54: 417-438. DOI: 10.1111/soru.12055.
Glauben T, Petrick M, Tietje H, Weiss C. 2009. Probability and timing of succession or closure in family firms: a switching regression analysis of farm households in Germany. Applied Economics 41: 45-54. DOI: 10.1080/00036840601131722.

Glauben T, Tietje H, Weiss C. 2004. Intergenerational succession in farm households: evidence from Upper Austria. Review of Economics of the Household 2: 443-462. DOI: 10.1007/ s11150-004-5656-4.

Graeub BE, Chappell MJ, Wittman H, Ledermann S, Kerr RB, Gemmill-Herren B. 2016. The state of family farms in the world. World Development 87: 1-15. DOI: 10.1016/j.world dev.2015.05.012.

Grubbström A, Sooväli-Sepping H. 2012. Estonian family farms in transition: a study of intangible assets and gender issues in generational succession. Journal of Historical Geography 38: 329339. DOI: 10.1016/j.jhg.2012.03.001.

Hautaniemi S, Gutmann MP. 2006. Land use and transfer plans in the U.S. great plains. Great Plains Research: A Journal of Natural and Social Sciences 844: 181-193.

Hennessy TC, Rehman T. 2007. An investigation into factors affecting the occupational choices of nominated farm heirs in Ireland. Journal of Agricultural Economics 58: 61-75. DOI: 10.1111/j.1477-9552.2007.00078.x.

HLPE. 2013. Investing in smallholder agriculture for food security. A report by the High Level Panel of Experts on Food Security and Nutrition of the Committee on World Food Security. Rome: HLPE.

Ingram J, Kirwan J. 2011. Matching new entrants and retiring farmers through farm joint ventures: insights from the fresh start initiative in Cornwall, UK. Land Use Policy 28: 917-927. DOI: 10.1016/j. landusepol.2011.04.001.

Inwood S, Sharp J. 2012. Farm persistence and adaptation at the rural-urban interface: succession and farm adjustment. Journal of Rural Studies 28: 107-117. DOI: 10.1016/j.jrurstud.2011.07.005.

Joosse S, Grubbström A. 2017. Continuity in farming - Not just family business. Journal of Rural Studies 50: 198-208. DOI: 10.1016/j.jrurstud.2016.11.018.

Kazakopoulos L, Gidarakou I. 2003. Young women farm heads in Greek agriculture: entering farming through policy incentives. Journal of Rural Studies 19: 397-410. DOI: 10.1016/S0743-0167 (03)00022-6.

Kerbler B. 2008. The influence of factors of the socio-geographical structure of mountain farms in Slovenia upon farm succession statuses and decisions. Acta Geographica Slovenica 48: 277-303. DOI: $10.3986 /$ AGS48203.

Kerbler B. 2012. Factors affecting farm succession: the case of Slovenia. Agricultural Economics 58(6): 285-298. DOI: 10.17221/ 47/2011-AGRICECON.

Kimhi A, Nachlieli N. 2001. Intergenerational succession on Israeli family farms. Journal of Agricultural Economics 52: 42-58. DOI: 10.1111/j.1477-9552.2001.tb00924.x.

Glover JL. 2014. Gender, power and succession in family farm business. International Journal of Gender and Entrepreneurship 6: 276-295. DOI: 10.1108/IJGE-01-2012-0006.

Lequieu AM. 2015. Keeping the farm in the family name: patrimonial narratives and negotiations among German-heritage farmers. Rural Sociology 80: 39-59. DOI: 10.1111/ruso.12046.

Lobley M, Baker J, Whitehead I. 2010. Farm succession and retirement: some international comparisons. Journal of Agriculture, Food Systems, and Community Development 1: 49-64. DOI: 10.5304/jafscd.2010.011.009.

Lowder SK, Skoet J, Raney T. 2016. The number, size, and distribution of farms, smallholder farms, and family farms 
worldwide. World Development 87: 16-29. DOI: 10.1016/j. worlddev.2015.10.041.

Mann S. 2007a. Tracing the process of becoming a farm successor on Swiss family farms. Agriculture and Human Values 24: 435-443. DOI: $10.1007 / \mathrm{s} 10460-007-9087-8$.

Mann S. 2007b. Understanding farm succession by the objective hermeneutics method. Sociologia Ruralis 47: 369-383. DOI: 10.1111/j.1467-9523.2007.00442.x.

May D, Arancibia S, Behrendt K, Adams J. 2019. Preventing young farmers from leaving the farm: investigating the effectiveness of the young farmer payment using a behavioural approach. Land Use Policy 82: 317-327. DOI: 10.1016/j. landusepol.2018.12.019.

Mishra AK, El-Osta H. 2007. Factors affecting succession decisions in family farm businesses: evidence from a national survey. Journal of the American Society of Farm Managers and Rural Appraisers: 1-10. DOI: 10.22004/ag.econ.190674.

Mishra AK, El-Osta HS. 2008. Effect of agricultural policy on succession decisions of farm households. Review of Economics of the Household 6: 285-307. DOI: 10.1007/s11150-008-9032-7.

Mishra AK, El-Osta H. 2010. Succession decisions in U.S. family farm businesses. Journal of Agricultural and Resource Economics 35. DOI: $10.2307 / 23243041$.

Morais M, Binotto E, Borges JAR. 2017. Identifying beliefs underlying successors' intention to take over the farm. Land Use Policy 68: 48-58. DOI: 10.1016/j.landusepol.2017.07.024.

Morais M, Borges JAR, Binotto E. 2018. Using the reasoned action approach to understand Brazilian successors' intention to take over the farm. Land Use Policy 71: 445-452. DOI: 10.1016/j. landusepol.2017.11.002.

Nuthall PL, Old KM. 2017. Farm owners' reluctance to embrace family succession and the implications for extension: the case of family farms in New Zealand. The Journal of Agricultural Education and Extension 23: 39-60. DOI: 10.1080/1389224X.2016.1200992.

O'Callaghan Z, Warburton J. 2017. No one to fill my shoes: narrative practices of three aging Australian male farmers. Aging \& Society 37: 441-461. DOI: 10.1017/S0144686x1500118X.

Otomo Y, Oedl-Wieser T. 2009. Comparative analysis of patterns in farm succession in Austria and Japan from a gender perspective. Jahrbuch der Österreichischen Gesellschaft für Agrarökonomie 18: 79-92.
Pitts MJ, Fowler C, Kaplan MS, Nussbaum J, Becker JC. 2009. Dialectical tensions underpinning family farm succession planning. Journal of Applied Communication Research 37(1): 59-79. DOI: 10.1080/00909880802592631.

Rayasawath C. 2018. Factors affecting the household succession in agricultural occupation in Nakhon Ratchasima Province, Thailand. Agriculture 8(7): 109. DOI: 10.3390/agricul ture8070109.

Santhanam-Martin M, Bridge P, Stevens L. 2019. Working with stuckness: lessons from an intervention to support intergenerational transitions on Australian dairy farms. Canadian Journal of Development Studies 40: 254-271. DOI: 10.1080/ 02255189.2018.1517302.

Stiglbauer AM, Weiss CR. 2000. Family and non-family succession in the Upper-Austrian farm sector. Cahiers d'Economie et de Sociologie Rurales 54: 5-26.

Suess-Reyes J, Fuetsch E. 2016. The future of family farming: a literature review on innovative, sustainable and successionoriented strategies. Journal of Rural Studies 47: 117-140. DOI: 10.1016/j.jrurstud.2016.07.008.

Tetteh I, Boehlje M. 2019. An intergenerational farm transfer: when to start handing over the reins? International Food and Agribusiness Management Review 22: 429-434. DOI: 10.22434/ IFAMR2018.0002.

Tsutsumi M. 2001. Succession of stem families in rural Japan: cases in Yamanashi Prefecture. International Journal of Japanese Sociology 10: 69-79. DOI: 10.1111/1475-6781.00008.

Uchiyama T, Lobley M, Errington A, Yanagimura S. 2008. Dimensions of intergenerational farm business transfers in Canada, England, the USA and Japan. The Japanese Journal of Rural Economics 10: 33-48. DOI: 10.18480/jjre.10.33.

Wheeler S, Bjornlund H, Zuo A, Edwards J. 2012. Handing down the farm? The increasing uncertainty of irrigated farm succession in Australia. Journal of Rural Studies 28: 266-275. DOI: 10.1016/j. jrurstud.2012.04.001.

Whitt C, MacDonald JM, Todd JE. 2019. America's diverse family farms: 2019 edition. [2020/07/20]. http://www.ers.usda.gov/pub lications/pub-details/?pubid=95546.

Zou B, Mishra AK, Luo B. 2018. Aging population, farm succession, and farmland usage: evidence from rural China. Land Use Policy 77: 437-445. DOI: 10.1016/j.landusepol.2018.06.001.

Cite this article as: Rodriguez-Lizano V, Montero-Vega M, Sibelet N. 2020. Which variables influence the succession process in family farms? A literature review. Cah. Agric. 29: 39. 